\title{
Biochemical Reaction
}

National Cancer Institute

\section{Source}

National Cancer Institute. Biochemical Reaction. NCI Thesaurus. Code C19899.

A chemical process, typically mediated by an enzyme, in which one or more substances (a

substrate) are transformed by covalent modification into another substance(s) (a

product) or in which the state of a substance is transformed. 